Studia z etyki i antropologii filozoficznej „Filozofia Chrześcijańska” 18 (2021), s. 65-77

\author{
AGNIESZKA BIEGALSKA \\ Uniwersytet Warmińsko-Mazurski w Olsztynie \\ Instytut Filozofii \\ doi: $10.14746 / \mathrm{fc} .2021 .18 .4$
}

\title{
O przeznaczeniu zła w myśli Leszka Kołakowskiego
}

Figura diabła w myśli Leszka Kołakowskiego nie jest abstraktem, diabeł Jest realny. Kim on jest? Co Kołakowski o nim wie? Co my o nim wiemy? Na ile go znamy? Wydaje się, że Kołakowski zna go dobrze - prowadzi z nim rozmowy, które często mają charakter intymny, opisuje go, opowiada o nim, definiuje. Można odnieść wrażenie, że panowie są zaprzyjaźnieni, a diabeł Kołakowskiego jawi się jako oddany człowiekowi, miły i życzliwy. „Stanowisko Kołakowskiego [w kwestii diabła - A.B.] cechuje skromność, a nawet pokora: na temat diabelskiego zła wypowiada się jak ktoś, kto nie tylko zła od innych ludzi doświadczył, ale też, ulegając diabelskim pokusom, sam je innym wyrządzał"'. Wydaje się, że takie doświadczenie zła jest bliskie każdemu z nas.

\section{Istnienie diabła. Demon i Bóg}

Kołakowski, podejmując problem unde malum?, pyta o rodowód naszego europejskiego diabła. W jego opinii pochodzenie demona jest niejasne i choć możemy prześledzić liczne legendy, podania i wierzenia, które opowiadają o narodzinach zła, to jednak powinniśmy porzucić nadzieję na znalezienie ostatecznej odpowiedzi na pytanie o jego proweniencję. Niemniej jednak Kołakowski przypuszcza, że „diabeł to największy bodaj wkład cywilizacji

${ }^{1}$ Z. Mentzel, Kołakowski. Czytanie świata. Biografia, Kraków 2020, s. 315. 
środkowo-azjatyckiej do kultury świata; bo też i w Grecji, jeśli odkrywamy gdzie jego ślady - jak w religii orfickiej - podejrzewamy w nich nie bez racji orientalny rodowód"'. Ten posługujący się wieloma imionami (Boruta, Rokita, Lucyfer, Belzebub, Mefistofeles, Asmodeusz...) przybysz ex Oriente zadomowił się u nas na dobre, wrósł w tradycję, umysły i serca Europejczyków. Wyobrażamy go sobie jako postać osobliwą - albo potężną, piękną, czasem obdarzoną olśniewającymi wielkimi skrzydłami, albo pokraczną i śmieszną, małą, przykurczoną, o niewinnym spojrzeniu, z ogonkiem i różkami. Ten drugi wizerunek zła traktujemy z przymrużeniem oka i oddajemy w ręce bajkopisarzy, natomiast ten pierwszy jest nam zdecydowanie bliższy, ponieważ zdaje się być hiperbolą nas samych - inteligentniejszych, bardziej pewnych siebie i zaradnych, obdarzonych zniewalającą urodą i nieprzeciętnym poczuciem humoru. Takimi chcielibyśmy być i takiego diabła wielu $\mathrm{z}$ nas byłoby skłonnych zaakceptować, szczególnie, że ten portret jest zbieżny z biblijnymi opisami upadłego anioła. Bóg w tej konfrontacji wypada niekorzystnie - „,wielki, barczysty, z bujną czupryną, ubrany z chłopska i prosto"3.

Ostatecznie jednak obie figury diabła uznajemy za nierzeczywiste. Latwo przychodzi nam porzucić myśl o diable. W dzisiejszym świecie wydaje się on przeżytkiem, jest symbolem zacofania, zabobonu i ciemnoty. Współczesnemu złu brakuje wyrazistych kształtów, realności - jest „nieszczęściem, przypadłością świata, czymś, co się przydarza, oczywiście, ale przydarza się po prostu, jak przydarzają się czasem dwugłowe cielęta, nie ma w tym musu żadnego [...]. Zło pasuje tylko do pojedynczych przypadków, dlatego nosi w waszej mowie odcień patetyczny, eksplozywny, naładowane jest waszą troską, waszym pragnieniem, zadumą, ufnością w przyszłość" "4. Kołakowski, nieobojętny na ewolucję ducha czasów, zauważa ponadto że „kultura liberalna z jeszcze większą niż komunizm konsekwencją doprowadza do zaniku wszystkich tych podpór, na których opiera się nasza cywilizacja, przede wszystkim kryteriów dobra i zła"5. Tak oto ta postać, niegdyś cieleśnie konkretna i swojska, rozproszyła się, rozpłynęła wraz z żywiołami, pośród których zwykła była bawić.

Jednak diabeł Kołakowskiego Jest - jest „,bezcielesnym rozumnym stworzeniem, którego wola jest zasadniczo zła, tzn. zdominowana jest całkowicie

${ }^{2}$ L. Kołakowski, O pożytkach diabła w: Pochwała niekonsekwencji. Pisma rozproszone z lat 1955-1968, t. 3, Warszawa 1989, s. 7.

${ }^{3}$ L. Kołakowski, Klucz niebieski albo Opowieści budujace z historii świętej zebrane ku pouczeniu i przestrodze, w: tenże, Bajki różneróżne. Opowieści biblijne. Rozmowy z diabłem, Warszawa 1990, s. 139.

${ }^{4}$ L. Kołakowski, Stenogram z metafizycznej konferencji prasowej Demona $w$ Warszawie dnia 20 grudnia 1963, w: tenże, Bajki różne..., s. 216.

${ }^{5}$ Z. Mentzel, Kolakowski..., s. 370. 
pragnieniem czynienia zła"6. Zły ciągle przeciw nam spiskuje, ciągle wypatruje naszej zguby i chce tylko niszczyć. Chodzi mu o niszczenie dla samego niszczenia, bez celu i usprawiedliwienia. Zło samo dla siebie jest racją. „Diabeł nie może być wyjaśniony, jest dany razem $z$ istnieniem waszym, jest rzeczą, jest tym, który jest" "

Kołakowski podjął próbę opisu własności zła i możliwość taką dostrzegł w zestawieniu zła z dobrem, diabła z Bogiem. Diabeł jest przeciwieństwem Boga. Skoro więc Bóg jest największy wśród całego stworzenia, to diabeł jest czymś najmniejszym w świecie, ,prawie nic, prope nihil’. Analogicznie, skoro Bóg jest najmocniejszy, to diabeł jest najsłabszy. Co ciekawe, swą bezsilność i brak mocy potrafił on skutecznie skierować przeciw wszechmocnemu Bogu. W akcie buntu przeciw porządkowi stworzenia doprowadził on do zmiany struktury świata - zło stało się jej składnikiem konstytutywnym. Tak więc okazuje się, że „diabeł nie jest etnograficzną ciekawostką, jest realną siłą w świecie" " Występując przeciw porządkowi Bożemu, stał się ,negacją ładu wewnątrz ładu”. Jako że „,demon nie może istnieć inaczej, jak w ruchu, którego orientalnym motywem jest spełnienie niszczycielskiego dzieła w sposób ostateczny", to zaspokojenie tej potrzeby destrukcji wymaga obecności ładu, który będzie podlegał niszczeniu, stąd ład stał się polem istnienia zła. W taki właśnie sposób myślimy o złu, jako „o czymś nie takim jak trzeba, o czymś, co stoi w opozycji do dobra, co mu się przeciwstawia, a nawet zaprzecza i co je niszczy"10.

Zdaniem Kołakowskiego, ,fakt upadku [...] nie może być niczym innym, jak dokonaną w czasie manifestacją czy aktualizacją pewnej potencji bytu bezwzględnie trwałej i odwiecznej""11. Jeśli demon jest współpierwotny Bogu, to rozstrzygnięcie, czy diabeł jest negacją ładu, czy ład jest negacją diabła, traci na znaczeniu. Wiadomo, że upadły anioł jest wpisany w naturę bytu, ale pozbawiony realnego dostępu do stworzonej przez Boga pozytywnej części bytu. Jest ona dla diabła „intelektualną nieuchronnością”, „realnością czysto graniczną pozytywnego wysiłku umysłowego", granicą, której dla własnego bezpieczeństwa diabeł nigdy nie przekroczy.

${ }^{6}$ L. Kołakowski, Diabel, w: tenże, Czy diabet może być zbawiony i 27 innych kazań, Kraków 2012, s. 248.

7 Tenże, Stenogram ..., s. 218.

${ }^{8}$ Z. Dymarski, Filozofia diabła Leszka Kołakowskiego, w: Studia z filozofii zła, red. R. Wiśniewski, Torun 1999, s. 189.

${ }^{9}$ L. Kołakowski, Stenogram ..., s. 219.

10 Z. Dymarski, Dwugłos o złu. Ze studiów nad myśla Józefa Tischnera i Leszka Kołakowskiego, Gdańsk 2009, s. 71.

${ }^{11}$ L. Kołakowski, Stenogram..., s. 219. 


\section{Upadek tradycyjnej teodycei i triumf diabła}

Mamy uzasadnione pretensje do Boga o kształt stworzenia. Świat jest „dziełem chaotycznym, bez myśli przewodniej, ma również fragmenty kiczowate, nieudolne, bez smaku; obcowanie z nim bywa często niemiłe"12 i tylko czasem rozbłyska w nim geniusz Stworzyciela. To samo powiedzieć można o człowieku stworzonym na obraz i podobieństwo Boga. Jego natura została ukształtowana w taki sposób, ,że dobroć jest na ogół skojarzona z powodzeniem, a ciężkie warunki życiowe pchają do występków, jednocześnie jednak [Bóg stworzył - A.B.] ludziom najgorsze właśnie warunki istnienia, jakie można sobie pomyśleć, a więc praktycznie olbrzymia większość grzęźnie po uszy w oszustwach, złodziejstwach, zawiści, intrygach i ślepych żądzach, nie mówiąc już o cudzołóstwie, które prawie się nie liczy na tle reszty grzechów"13. Autorzy teodycei ten niezadowalający stan świata thumaczą tym, że Bóg stworzył człowieka jako istotę wolną, a tym samym zdolną do czynienia zła, i to w nasz ludzki wolny akt wyboru wpisana jest odpowiedzialność za zło świata. Jednak wydaje się, że człowiek jest usprawiedliwiony, ponieważ czyni zło z podwójnej konieczności - z faktu, że zło jest trwałym elementem świata i stworzenia człowieka $z$ wolnością. „Bo choć człowiek zło zapoczątkowuje, to jest ono w pewien sposób zastane"14. Bóg we wszechmocy swej mógł stworzyć świat bez zła, ale byłby to świat zdecydowanie gorszy od świata, w którym mieszkają wolne jednostki, i dlatego doskonały ze stworzenia świat wytwarza najmniejszą możliwą ilość zła. Minimum chrześcijańskie to ,wiara, iż Jezus-odkupiciel w historycznym czasie zjawił się na ziemi, aby ludzi wyzwolić od zła, od którego sami wyzwolić się nie mogli, oraz płynąca $\mathrm{z}$ tej wiary zdolność do usunięcia nienawiści" ${ }^{15}$. Chrześcijaństwo wymaga zatem ,zdolności do radykalnego odsłaniania przed samym sobą własnego zła" ${ }^{16}$ i rezygnacji z nienawiści bez względu na okoliczności. Ostatecznie jednak teodycea pomija oczywisty fakt, że ,istnienia zła nie da się wyjaśnić jedynie przez wskazanie na człowieka jako sprawcę zła, zła, do którego dochodzi poprzez nadużycie wolnej woli. Suma niegodziwości, o jakie potykamy się co krok w naszej drodze życiowej, przekracza nawet najbardziej zdeprawowane siły człowieka" ${ }^{17}$.

12 Tenże, Klucz niebieski..., s. 109.

13 Tamże, s. 139.

14 Z. Dymarski, Filozofia diabła..., s. 187.

15 L. Kołakowski, O tak zwanym kryzysie chrześcijaństwa, w: tenże, Czy diabeł może być zbawiony..., s. 231.

16 Tamże, s. 233.

17 Jan A. Kłoczowski, Zło czy zły?, „Znak”1993, nr 454 (3), s. 38. 
Kołakowski obala więc tradycyjną teodyceę, twierdząc, że Bóg mógł przecież stworzyć istoty wolne, które mogą czynić zło, ale go nie czynią. Ponadto, zdaniem Kołakowskiego, tezy teodycei nie są pozytywnym dowodem na prawdziwość jakiejkolwiek teorii. Teodycee są potrzebne tym, którzy nie chcą się pogodzić, ,że cierpienie i zło są po prostu cierpieniem i złem, nagimi faktami, które nic nie znaczą, nie odnoszą się do niczego i niczym nie są usprawiedliwione" ${ }^{\prime 1}$. Faktami bowiem rządzą jedynie prawidłowości przyrodnicze i przypadki, które pozbawione są sensu. Świat powstał bez konkretnego celu i podąża swoim biegiem, a „ostateczne dzieje wszechświata zdają się historią porażki Bytu w starciu z Nicością; materia, życie, gatunek ludzki, inteligencja i twórczość człowieka - wszystko to musi skończyć się zagładą; wszystkie nasze wysiłki, cierpienia i przyjemności przepadną na zawsze w pustce, nie pozostawiając po sobie żadnych śladów"19. Na człowieka nie czeka żadna nagroda, żadne zbawienie.

Co zatem $\mathrm{z}$ deklarowaną przez Boga odwieczną dobrocią i miłością? Miłość Boga do pierwszych ludzi, do narodu wybranego, do każdego człowieka okazała się nikłej wartości, ponieważ „przez grzech żyjemy na świecie, przez ten sam grzech umieramy i przez ten sam grzech na wieczne skazujesz nas potępienie, a grzech ten to miłość właśnie, która z Ciebie płynie, bo Tyś się Bogiem miłości mianował"20.

Inaczej sprawa ma się z diabłem. Otóż złożył on pierwszym ludziom obietnicę, że po zjedzeniu owocu $\mathrm{z}$ drzewa $\mathrm{w}$ raju nie umrą, i nie umarli. Oczywiście Bóg nieustannie podtrzymuje swą obietnicę miłości, ale wymaga, byśmy w drodze ku niej odwrócili się od zła, znienawidzili je. Zatem to nienawiść ma stać się drogą ku miłości. Bóg jest dobry

o ile przejawia swoją istotę, czyni dobro; człowiek chwaląc go chwali dobro, którego doznał - co nie jest żadną zasługą. A więc prawdziwy triumf Jehowy przejawia się tam, gdzie bywa chwalony za zło, to znaczy, gdzie działa wbrew swojej istocie, czyli Jehowa o tyle odnosi zwycięstwa, o ile ukazuje się innym, niż jest naprawdę. Żeby je stale odnosić, musi stale występować w roli złoczyńcy, stąd ludziom płytko myślącym zdaje się, że Jehowa urządził świat bardzo marnie. W rzeczywistości urządził go bardzo mądrze: mnoży nieszczęścia ludzkie, bo przez nie dostępuje moralnych zwycięstw; gdyby ludzie byli szczęśliwi, Szatan miałby małe sukcesy, ale Bóg żadnych. Widać tedy, że aby furtka niebios otwierała się dla jednostek, miliony muszą pędzić przez bramy piekielne ${ }^{21}$.

${ }^{18}$ L. Kołakowski, Jeśli Boga nie ma..., w: tenże, Jeśli Boga nie ma... Horror metaphysicus, tłum. T. Baszniak, M. Panufnik, Kraków 1988, s. 30.

19 Tamże, s. 30.

${ }^{20}$ Tenże, Modlitwa Heloizy, kochanki Piotra Abelarda, kanonika i teologa, w: tenże, Bajki różne..., s. 202.

${ }^{21}$ Tenże, Klucz niebieski..., s. 144. 


\section{Triumf diabła. Ujęcie pozakonfesyjne}

Kołakowski pyta o diabła również w kontekście świeckich teorii zbawienia i zwraca uwagę na poczucie winy jako elementu konstytutywnego natury ludzkiej. „Nie przyświadczamy bowiem naszych moralnych wierzeń przez uznanie ich prawdy, lecz przez poczucie winy, gdy je gwałcimy" ${ }^{22}$. Nie czujemy się winni z obawy przed karą czy z powodu intelektualnego aktu wyboru niewłaściwego sądu wartościującego. Poczucie winy jest ,poczuciem grozy w obliczu własnego czynu, który zakłócił harmonię świata, lęk płynący z naruszenia nie prawa, lecz tabu. Nie tylko ja zagrożony jestem przez okropność mojego uczynku, zagrożona jest całość wszechświata, który pogrąża się jakby w chaosie i niepewności" ${ }^{\prime 23}$. Wina rodzi lęk z powodu naruszenia tabu, które jest rdzeniem każdego systemu moralnego oraz niezmiennym składnikiem życia religijnego. „Tabu tworzy zatem konieczną więź między kultem rzeczywistości wiecznej a znajomością dobra i zła. Ten kult i ta znajomość działają łącznie i nie mogą przetrwać bez siebie" ${ }^{24}$.

Tabu jest obecne zarówno w rzeczywistości, jak i percepcji ludzi, którzy je odczuwają, i żyje tak długo, jak długo wzbudza się w nas poczucie winy. Pierwotnie tabu mogło być wyrazem biologicznych zahamowań, ale z czasem przyjęły one formę sakralnych nakazów i „moc instynktu została utracona na rzecz kultury". Tak więc, kultura stała się zbiorem tabu. W ten sposób „Związek naszej percepcji dobra i zła z dziedziną sacrum jest wyraźniejszy, niż mogłyby to sugerować jakiekolwiek dyskusje semantyczne i uwidacznia się on w samym pojęciu kultury"25.

W religiach monoteistycznych relacja dobra do zła jest ściśle określona: dobro względem zła jest uprzywilejowane, to ono naprawdę istnieje i w porządku bytu jest pierwotne. Zło zostaje usunięte $\mathrm{z}$ bytu i zepchnięte w otchłań nicości. W doświadczeniu pozakonfesyjnym dobro i zło nie różnią się od przyjemności i bólu. Zatem smutek, strach, cierpienie i śmierć uznajemy za fakty naturalne i z oczywistych powodów chcemy ich unikać. Moralne rozróżnienie dobra i zła jest możliwe dzięki ludzkiemu uczestnictwu w tabu.

Naprawdę wiemy, czym jest dobro, wiedząc, czym jest zło, zło zaś poznajemy przez to, że je czynimy. W doświadczeniu odwrotnie niż w teologicznej spekulacji, zło musi pojawić się pierwsze. A pierwsze zło, jakie znam, to zło we mnie samym, podczas gdy zło w innych ludziach (i tu - jako różne od faktów naturalnych) jest pochodne. W doświadczeniu porażki, gdy widzimy Byt pokonany

\footnotetext{
${ }^{22}$ Tenże, Jeśli Boga nie ma..., s. 160.

23 Tamże.

${ }^{24}$ Tamże, s. 161.

${ }^{25}$ Tamże, s. 163.
} 
przez nicość, powstaje wiedza o Bycie i o dobru. Sam stając się zły, wiem, czym jest zło, a wtedy - czym jest i dobro ${ }^{26}$.

Zatem jeśli Boga nie ma, to my sami decydujemy o tym, co jest dobre, a co złe, i „zawsze można dowieść, że cokolwiek czynimy, jest dobre"27. Świeckie podejście, choć „nie ma dostępu do epistemologicznego absolutu ani uprzywilejowanego dojścia do absolutnego Bytu, które mogłoby dać w rezultacie wiarygodną wiedzę teoretyczną", to jednak odsłania możliwość metafizycznej intuicji ,,jako rezultat naszego życia w królestwie dobra i zła oraz doświadczania ich jako własnych" ${ }^{28}$. Ta świadomość dobra i zła jest konstytutywna dla ego i odsłania się dopiero w doświadczeniu upadku. Staniemy się więc sobą ,jedynie przez uznanie ciążącej na nas winy" ${ }^{\prime 29}$.

\section{Zło złem zwyciężaj}

Za bezsporny fakt uznać powinniśmy, że zło Jest. Okazuje się jednak, że całkowite pogodzenie się z jego obecnością najprawdopodobniej uniemożliwiłoby człowiekowi jakiekolwiek funkcjonowanie. Zatem optymalne wydaje się mieć nadzieję na to, że minimalizujmy zło i że kiedyś uda nam się je unicestwić. Taka wiara musiałaby zakładać naszą ludzką moc sprawczą ostatecznego zgładzenia zła. Zdaniem Kołakowskiego, ,potrafimy uruchomić energie, jakie są potrzebne do osiągnięcia rezultatów skończonych" ${ }^{30}$. Jednak sama wiara w ostateczne zniesienie zła jest tylko złudzeniem i jedynie rozgrzewa serce diabła. „Obietnica totalnego zbawienia, nadzieja na dobroczynną apokalipsę, która przywróci człowiekowi jego niewinność, sprzeciwia się zarówno rozumowi, jak naszemu prawu do życia jednostkowego" "31. Zawsze bowiem mamy poczucie własnej niedoskonałości, która przejawia się jako zdolność do wątpienia. Wątpienie pełni funkcję ochrony przed innymi, groźniejszymi skutkami ludzkiego postępowania. „Jest ważne, byśmy żyli w niepewności co do ukrytych motywów własnych czynów i co do racji własnych przekonań, jest to bowiem jedyne urządzenie, które broni nas przed wszystko usprawiedliwiającym fanatyzmem i nietolerancją"32. Wprawdzie wątpienie zapobiega

26 Tamże, s. 164.

27 Tamże, s. 168.

28 L. Kołakowski, Jeśli Boga nie ma... Horror metaphysicus, s. 272.

29 J. Tokarski, Obecność zła. O filozofii Leszka Kołakowskiego, Kraków 2016, s. 340.

30 L. Kołakowski, Czy diabet może być zbawiony, w: tenże, Czy diabeł może być zbawiony..., S. 220

31 Tenże, Czy diabet..., s. 221.

32 Tamże. 
temu, by zło osiągnęło w nas pełnię, jednak, paradoksalnie, to ono okazuje się źródłem zła. Wątpienie jest bowiem dla umysłu niszczące, ustawicznie przypomina człowiekowi o jego niedoskonałości, ale w ten właśnie sposób zapobiega eskalacji zła w nas i osłabia nasze zaufanie do siebie, przeciwstawiając się złu. Z drugiej strony może się ono stać narzędziem dla diabła, który będzie je potęgował tak, aż podpadniemy w niemoc, bezczynność i zupełnie zaniechamy walki ze złem.

Jest jeden sposób na zwalczanie zła - prosty i skuteczny, choć może wydać się zaskakujący: ,zło pokusy złem uczynku precz wygnać”. Chodzi o to, by nie dopuszczać do rozkwitu i trwania w nas pokus, lecz od razu przejść do czynu „kiedy złodziejstwo - złodziejstwo, kiedy zabójstwo - zabójstwo, kiedy gniew - gniew" "33. Zatem lekarstwem na zło jest zło, ponieważ „upadły może $\mathrm{z}$ upadłym się zmagać, boć trzeba $\mathrm{w}$ tej samej przepaści siedzieć, aby wojnę prowadzić" "34. Obierając tę drogę, zawsze tkwimy w mocy zła, wówczas pozostaje nam pogodzić się z tym faktem albo prosić o pomoc sprawiedliwość Bożą.

Jeśli o potępienie błagać będziecie nędzę swoją przejrzawszy, najmilsi, wysłucha Pan waszego wołania; jeśli tedy szatana w pokorze weźmiecie za towarzysza, jeśli w pokorze grzeszność swoją grzechem pogłębiać będziecie, grzech do grzechu codziennie dodając, co godzina, co chwila, jeśli zło ze złem większym kojarzyć będziecie, och, kochani moi, najmilsi moi, bracia moi i siostry - i wtedy stanie się wam wedle miary grzeszności waszej ${ }^{35}$.

Jeśli uwierzymy, że każde zło, które nas spotyka, jest wynikiem działania złej siły, to wówczas możemy próbować mu zaradzić. Jeśli zaś założymy, że Bóg dopuszcza zło na nas z jakiegoś sobie znanego powodu, to nie robimy nic i popadamy w coraz większą nędzę. Wybór drogi radzenia sobie ze złem należy do każdego z nas, pamiętać jednak należy, że „zło na ziemi jest nieuchronne i nigdy do końca nie będzie zlikwidowane ludzkimi siłami”"36. Pozostaje nam jedynie ,uprawiać sztukę balansowania przeciwstawnych niebezpieczeństw”.

\section{Działanie i rola diabła w ludzkim życiu}

Przybyłą ze Wschodu do Europy figurę diabła pierwsze zaadoptowało chrześcijaństwo, które uznało rzeczywisty, a nawet osobowy charakter demona. Ta charakterystyka zła stanęła w konflikcie z obrazem osobowego,

\footnotetext{
${ }^{33}$ L. Kołakowski, Wielkie kazanie księdza Bernarda, w: tenże, Bajki różne..., s. 184.

34 Tamże, s. 186.

${ }^{35}$ Tamże, s. 187.

${ }^{36}$ Z. Dymarski, Filozofia diabła..., s. 183.
} 
wszechmocnego i wyłącznie dobrego Boga. Teologia, chcąc ocalić własności Boga, ocaliła również diabła, choć zepchnęła go do niebytu, nadając mu wyłącznie negatywne znaczenia. Jednakże „w chrześcijaństwie potocznym, obiegowym diabeł był najzupełniej realny, najbardziej konkretny, cieszył się rzeczywistością nie gorszą, a bodaj lepszą, bardziej namacalną i bardziej przejmującą aniżeli wszystkie dziewięć szczebli hierarchicznych anielskiego porządku"37.

Zdaniem Kołakowskiego, doskonale znamy diabła i ,jeśli w ogóle coś znamy, to właśnie albo tego właśnie - tego małego, chytrusa, podleca, prześmiewcę, szydercę, okrutnika"38. Dziwna jest to znajomość, bo ów znany jest ostatecznie zupełnie nam nieznany. Wprawdzie służymy mu w każdej minucie naszego życia, lecz nie wiemy, komu służymy. Okazuje się, że diabeł mieszka w nas - w duszy i w ciele, bo choć jest bezcielesny, to może działać cieleśnie. Najlepszym jego mieszkaniem są ludzkie dobre myśli i uczynki, ponieważ diabeł każde dobro potrafi przemienić w zło. Dlatego odnajdujemy zło w naszych wszystkich porażkach, niepowodzeniach i zwątpieniach, w strachu i wstydzie, a także w naszej próżności i pysze. Diabeł atakuje nasze najsłabsze miejsca, a największą jego bronią jest kłamstwo - obiecuje i nie dotrzymuje obietnic. Siła Szatana tkwi w tym, że ,moralna strona każdego działania - w przeciwieństwie do strony technicznej - jest absolutnie nieprzewidywalna i daje się zrozumieć i ocenić dopiero po fakcie" "39. Orientujemy się więc co do skutków naszego działania już po uczynku, a nie na poziomie naszych intencji.

Diabeł zawładnął również tym obszarem ludzkiego życia, który wydawał się najbardziej nasz, ludzki - miłością. Miał to też być obszar uprzywilejowanego kontaktu człowieka z Bogiem, wszak ,kto nie miłuje, nie zna Boga, bo Bóg jest miłością" ${ }^{40}$. Kołakowski sugeruje w tym miejscu, że „być może stało się tak dlatego po prostu, że od początku diabeł wziął pod swoją opiekę całą dziedzinę ludzkiej miłości cielesnej i, być może, sytuacja wspomniana jest dla nas bardziej widoczna, im bardziej jesteśmy świadomi, że prócz cielesnej nie ma innej miłości, jako że sami nie jesteśmy niczym innym jak tylko ciałem"41.

Diabeł, choć jego natura jest zupełnie zła, ma jednak pewne niekwestionowane zalety. Otóż, stając się trwałą częścią ludzkiego życia, zgodził się przyjąć na siebie całe zło naszego świata. Okazał się więc ,wynalazkiem bezcennym”. Najpierw przejął na siebie odpowiedzialność za nasze żądze, a z czasem zawładnął całą ziemską naturą, całym naszym doczesnym życiem. „Szatan usprawiedliwiał przed Bogiem nasze grzechy, ale stworzył sytuację, w której nasz rozum,

\footnotetext{
${ }^{37}$ L. Kołakowski, O pożytkach diabła, w: tenże, Pochwała niekonsekwencji, s. 8.

${ }^{38}$ Tenże, Wielkie kazanie..., s. 177.

39 Tenże, Klucz niebieski..., s. 150.

40 1 J,4,8, w: Biblia Tysiaclecia, https://biblia.deon.pl/ [dostęp: 9.04.2021].

${ }^{41}$ L. Kołakowski, O pożytkach diabła, s. 13.
} 
nasza wiedza i technika potrzebowały takiego samego usprawiedliwienia jak nasze złodziejstwa"42. Ostatecznie diabeł doprowadził do sytuacji, w której wszystkie ludzie akty związane z wykonywaniem woli stały się jego własnością, bo właśnie realizując swą wolę, człowiek staje się złu najbardziej podobny.

W tym kontekście ludzka walka ze złem okazuje się walką człowieka z samym sobą, a próba rehabilitacji natury staje się jednocześnie rehabilitacją diabła. Ludzkość popadła w paradoks: ,nie diabeł jest sprawcą ludzkich nieszczęść, ale ludzkie nieszczęścia są źródłem diabła"43.

W konkluzji stwierdzić należy, że ,świat bez diabła byłby trudny do zniesienia, żądałby od nas odpowiedzialności za wszystko, całe zło tego świata musielibyśmy ponieść my, ludzie, na własnych ramionach" ${ }^{44}$. Po wtóre, „obecność jego utrzymuje w nas wrażliwość na zło; sprawia, że jesteśmy czujni i sceptyczni w obliczu optymistycznych nadziei na totalne zbawienie wszystkiego i na ostateczne pogodzenie wszystkich energii działających we wszechświecie" ${ }^{45}$. Kołakowski postuluje, że w świecie jest określona suma zła, której nie można ze świata usunąć. Oznacza to, że nasze cierpienie z powodu doznawania zła jest nieuleczalne.

\section{Zakończenie}

Stanowisko Kołakowskiego w kwestii diabła nie uległo zmianie do końca jego życia. W trzydzieści lat po konferencji na temat demona w Warszawie „,zapytany, co się przez te trzy dziesięciolecia w metodach i działaniach diabła zmieniło”46, odpowiedział: „W piekle bez zmian”. A piętnaście lat później zapytany o kondycję diabła odrzekł: „Nie, nie zmienił się diabeł [...] a i myśmy się nie zmienili. Nadal praca diabła na tym polega głównie, by nasze dobre strony nienawiścią zatruć, do złego użyć, na pożytek diabła obrócić; i nadal poddajemy się łatwo i z małym oporem, albo z żadnym oporem jego kuszeniu"47. Zawsze jednak towarzyszyło Kołakowskiemu poczucie braku wniosków o charakterze ostatecznym. Pisał o tym w Czy Pan Bóg jest szczęśliwy i inne pytania:

Jak we wszystkim prawie, com pisał $\mathrm{w}$ ostatnich latach kilkudziesięciu, nie potrafię w sprawach najważniejszych dotrzeć do konkluzji ostatecznych i ciągle

\footnotetext{
42 Tamże, s. 9.

43 Tamże, s. 12.

44 Tamże, s. 8.

45 L. Kołakowski, Diabet, s. 276.

46 Z. Mentzel, Kolakowski..., s. 321.

47 Tamże, s. 321.
} 
potykam się o kłopoty, które trzeba wyminąc niezręcznym i uciekinierskim powiedzeniem „,z jednej strony..., ale z drugiej strony”. Być może jest to przypadłość czy może raczej ułomność umysłu autora, być może jednak - znów sobie pochlebiam - przypadłość bytu ${ }^{48}$.

A w Horror metaphysicus zanotował: „Nie możemy zgłębić tajemnicy i obrócić jej w wiedzę, lecz ważne wiedzieć, że mamy z nią do czynienia; choć nie sposób zedrzeć zasłonę, za którą ukrywa się rzeczywistość ostateczna, winniśmy wiedzieć, że jest taka zasłona"49.

Wszystkim pragnącym odsłonić zasłonę Kołakowski proponuje przyjąć postawę niekonsekwencji, która niesie ze sobą ,odmowę raz na zawsze przesądzającego wyboru między jakimikolwiek wartościami alternatywnie się wykluczającymi" ${ }^{50}$. Do takiej tezy skłoniła go obserwacja natury rzeczywistości ludzkiego życia, która cały czas oscyluje między sprzecznościami. Sprzeczności te w sposób immanentny są zawarte w świecie, zatem nie można ich w żaden sposób uzgodnić. Każde z ekstremów jest ważne, bo każde jest wartością. Kołakowski przyznaje, że istnieje możliwość przezwyciężenia sprzeczności aktualnie istniejących, ale w miejsce zniesionych pojawią się nowe. Targani przez antynomie pamiętać musimy, że są ,sytuacje elementarne, gdzie zamiera taktyka, to jest takie sytuacje ludzkie, do których nasz stosunek moralny pozostaje niezmienny ze względu na okoliczności, w jakich te sytuacje dochodzą do skutku. [...] Elementarnymi sytuacjami są ewidentne agresje wojenne, ludobójstwo, tortury, znęcanie się nad bezbronnymi"51. W takich sytuacjach postawa niekonsekwencji załamuje się i powraca świat dwóch wartości, czyli świat dobra i zła.

Dobro w naszej kulturze związane jest z myślą o Jedni, Absolucie, Bogu, który „,przy próbie sprowadzenia do formy doskonałej, nie skażonej kontaktem z jakąkolwiek mniej wysublimowaną rzeczywistością, odpływa w nicość" "52, staje się pustym pojęciem. Bóg religii, któremu przypisujemy cechy takie jak: bezczasowość, nieskończoność, wieczność i spełnienie, musi zostać utożsamiony z Absolutem, a wówczas, żadne dobro nie powiększa jego zasobów, a zło nie umniejsza. Nie ma więc, ,ani dobra, ani zła, i a fortiori żadnej między nimi różnicy" ${ }^{53}$. Z kolei spuścizna cywilizacyjna przyzwyczaiła nasze umysły do myśli, że to cogito, wybierając między dobrem a złem, przyczynia się do budowania lub nadwątlania dobra.

${ }^{48}$ L. Kołakowski, Czy Pan Bóg jest szczęśliwy i inne pytania, Kraków 2009, s. 5.

${ }^{49}$ Tenże, Jeśli Boga nie ma... Horror metaphysicus, s. 201.

${ }^{50}$ Tenże, Pochwała niekonsekwencji, w: tenże, Pochwała niekonsekwencji. Pisma rozproszone z lat 1955-1968, t. 2, Warszawa 1989, s. 156.

${ }_{51}$ Tamże, s. 160.

${ }^{52}$ L. Kołakowski, Jeśli Boga nie ma... Horror metaphysicus, s. 238.

${ }^{53}$ Tamże, s. 265. 
Wprawdzie nie mamy dostępu do Absolutu, który mógłby odsłonić przed nami wiarygodną wiedzę teoretyczną na temat dobra i zła, jednak w każdym z nas jest intuicja, że doświadczane dobro i zło jest moje. Ta intuicja istnienia dobra i zła nie pochodzi z ,intelektualnej intuicji absolutu bądź egzystencjalnej intuicji cogito", lecz „z ruchu, który, jak mniemamy, powoduje wzrost bądź kurczenie się Bytu w wyniku dobra lub zła naszych czynów. Byt staje się zrozumiały w ramach samopostrzegania dobra i zła" ${ }^{54}$. Ta świadomość dobra i zła jest konstytutywna dla ego, co pozwala nam utwierdzać się w byciu sobą.

Diabeł jest więc inherentny zarówno światu, w którym żyjemy, jak i ego, którym jesteśmy, i to siła zła, a nie dobra wzmaga naszą czujność i wrażliwość na zło. $Z$ tych powodów nigdy nie powinniśmy chcieć zniknięcia zła $\mathrm{z}$ naszej rzeczywistości.

\section{On the Destiny of Evil in LesZek KoŁakowski’s Thought}

\section{S UMMAR Y}

In Leszek Kołakowski's thought, a devil is not abstract but real. What does he know about it? What do we know? How much of it do we know? It seems that Kołakowski knows it well - he speaks with it, discusses it, and defines it. As if they both were friends. 'The devil by Kołakowski' seems to be human-friendly and supportive. Thus, the article poses the following questions: What is the role of evil as defined by Kołakowski in human world and life? How does it work? What is its destiny?

Keywords: Leszek Kołakowski, devil, God, evil, good, new theodicy, taboo

Słowa kluczowe: Leszek Kołakowski, diabeł, Bóg, zło, dobro, nowa teodycea, tabu

\section{BIBLIOGRAFIA}

1 List św. Jana, w: Biblia Tysiaclecia, https://biblia.deon.pl/ [dostęp: 9.04.2021].

Dymarski Z., Dwugłos o złu. Ze studiów nad myśla Józefa Tischnera i Leszka Kołakowskiego, Gdańsk 2009.

Dymarski Z., Filozofia diabła Leszka Kołakowskiego, w: Studia z filozofii zła, red. R. Wiśniewski, Torun 1999, s. 181-195.

Kłoczowski J.A., Zło czy zły?, „Znak” 1993, nr 454 (3), s. 29-40.

54 Tamże, s. 269. 
Kołakowski L., Czy diabeł może być zbawiony, w: L. Kołakowski, Czy diabet może być zbawiony i 27 innych kazań, Kraków 2012, s. 211-223.

Kołakowski L., Czy Pan Bóg jest szczęśliwy i inne pytania, Kraków 2009.

Kołakowski L., Diabet, w: L. Kołakowski, Czy diabet może być zbawiony i 27 innych kazań, Kraków 2012, s. 248-276.

Kołakowski L., Jeśli Boga nie ma..., w: L. Kołakowski, Jeśli Boga nie ma... Horror metaphysicus, thum. T. Baszniak, M. Panufnik, Kraków 1988, s. 9-192.

Kołakowski L., Klucz niebieski albo Opowieści budujące z historii świętej zebrane ku pouczeniu i przestrodze, w: L. Kołakowski, Bajki różne. Opowieści biblijne. Rozmowy z diablem, Warszawa 1990, s. 107-270.

Kołakowski L., Modlitwa Heloizy, kochanki Piotra Abelarda, kanonika i teologa, w: L. Kołakowski, Bajki różne. Opowieści biblijne. Rozmowy z diabłem, Warszawa 1990.

Kołakowski L., O pożytkach diabła, w: L. Kołakowski, Pochwała niekonsekwencji. Pisma rozproszone z lat 1955-1968, t. 3, Warszawa 1989, s. 7-13.

Kołakowski L., O tak zwanym kryzysie chrześcijaństwa, w: L. Kołakowski, Czy diabet może być zbawiony i 27 innych kazań, Kraków 2012, s. 224-233.

Kołakowski L., Pochwała niekonsekwencji, w: L. Kołakowski, Pochwała niekonsekwencji. Pisma rozproszone z lat 1955-1968, t. 2, Warszawa 1989, s. 154-160.

Kołakowski L., Stenogram z metafizycznej konferencji prasowej Demona $w$ Warszawie dnia 20 grudnia 1963, w: L. Kołakowski, Bajki różne. Opowieści biblijne. Rozmowy z diabłem, Warszawa 1990, s. 213-223.

Kołakowski L., Wielkie kazanie księdza Bernarda, w: L. Kołakowski, Bajki różne. Opowieści biblijne. Rozmowy z diabtem, Warszawa 1990, s. 177-187.

Mentzel Z., Kolakowski. Czytanie świata. Biografia, Kraków 2020.

Tokarski J., Obecność zła. O filozofii Leszka Kołakowskiego, Kraków 2016. 